\title{
Seasonal changes in plasma testosterone concentrations and Leydig cell and accessory gland activity in the Cape horseshoe bat (Rhinolophus capensis)
}

\author{
R. T. F. Bernard \\ Department of Zoology and Entomology, Rhodes University, Grahamstown 6140, South Africa
}

\begin{abstract}
Summary. Male Cape horseshoe bats were studied in the Cape Province of South Africa $\left(33^{\circ} 17^{\prime} \mathrm{S}, 26^{\circ} 25^{\prime} \mathrm{E}\right)$ between January 1983 and June 1985 . The reproductive cycle is characterized by reactivation of the seminiferous tubules in early summer (October) after a 4-month (June to September) period of winter inactivity. Spermiogenesis occurred between January and April, and spermatozoa were released to the epididymides in April and May. Spermiogenesis was associated with Leydig cell activity and increasing plasma testosterone concentrations. At this time components of the reproductive accessory glands became secretorily active or showed increasing secretory activity. During winter Leydig cells were secretorily inactive and plasma testosterone concentrations dropped, but components of the accessory complex remained active. There was a second period of Leydig cell secretory activity and increasing and peak plasma testosterone values in late winter/early summer which may be associated with copulation or the initiation of a new cycle of spermatogenesis.
\end{abstract}

\section{Introduction}

The reproductive cycles of male hibernating bats of the families Rhinolophidae and Vespertilionidae (excluding the Miniopterinae) are characterized by an asynchrony between primary and secondary reproductive processes (Wimsatt, 1969; Racey \& Tam, 1974; Gustafson, 1979; Racey, 1982). This asynchrony is apparent initially during winter when the accessory glands appear active while the seminiferous tubules are inactive (Gustafson, 1979), and again in the period after hibernation when the seminiferous tubules and accessory glands undergo reactivation (Racey \& Tam, 1974; Gustafson, 1979; Racey, 1982). Reactivation of the seminiferous tubules occurs at the beginning of summer (Racey, 1982) and spermatogenesis is associated with increasing and elevated concentrations of plasma testosterone (Racey, 1974; Racey \& Tam, 1974; Gustafson \& Shemesh, 1976). However, the accessory glands do not respond to these elevated plasma testosterone concentrations, becoming secretory only after spermatogenesis has terminated (Gustafson, 1979).

There is very little information regarding the endocrine control of male reproduction and particularly the asynchrony between activity of primary and secondary reproductive organs shown by these hibernating bats. Numerous authors (see Gustafson, 1979, for review) have described seasonal changes in Leydig cell morphology and/or secretory activity that indicate the occurrence of two patterns of Leydig cell activity. In the first, the Leydig cells are active during spermatogenesis and remain active during winter hibernation ('Pipistrellus pattern'), while in the second, the Leydig cells are active during spermatogenesis but regress before winter hibernation ('Myotis pattern') (Gustafson, 1979). The limited data on plasma testosterone values support the existence of the two patterns of Leydig cell activity. The little brown bat (Myotis lucifugus) shows depressed concentrations of plasma testosterone during winter (Gustafson \& Shemesh, 1976), while the 
common pipistrelle (Pipistrellus pipistrellus) has elevated plasma testosterone concentrations at this time (Racey \& Tam, 1974).

The aim of this study was to describe the seasonal changes in Leydig cell activity, plasma testosterone concentrations and accessory gland secretory activity of the Cape horseshoe bat so as to add to the limited pool of data pertaining to the phenomenon of reproductive asynchrony and its hormonal control. Members of the genus Rhinolophus for which data are available are characterized by continued secretory activity of Leydig cells and accessory glands during winter (Courrier, 1927) and as such belong in the 'Pipistrellus pattern' (Gustafson, 1979). The reproductive cycle of the Cape horseshoe bat is similar to those of north temperate-zone members of the genus with the significant difference that copulation occurs only at the end of winter (Bernard, 1985).

\section{Materials and Methods}

Specimens of male Cape horseshoe bats (Rhinolophus capensis) were collected every month during the first year of the study, and every 2 months, with supplementary collections at important times, in the second and third years. Material for the examination of Leydig cell ultrastructure and accessory gland histochemistry was collected between January 1983 and June 1984, while material for accessory gland ultrastructure and blood for testosterone assay were collected between January 1984 and June 1985 . All specimens were obtained from a tunnel on Table Farm $\left(33^{\circ} 17^{\prime} \mathrm{S}, 26^{\circ} 25^{\prime} \mathrm{E}\right)$ in the Cape Province of South Africa.

Light microscopy. Specimens were killed by asphyxiation with $\mathrm{CO}_{2}$ and the accessory gland complex immediately removed and fixed in buffered neutral formalin or $10 \%$ alcoholic formalin. Tissues were embedded in Paraplast, sectioned at $5 \mu \mathrm{m}$, and stained with Ehrlich's haematoxylin and eosin, McManus PAS or alcian blue.

Activity of the three components of the accessory gland complex was quantified by measuring the height of the secretory epithelium in at least 20 places from a minimum of three specimens per month.

Electron microscopy. Small pieces of testis and pieces of the three components of the accessory gland complex were fixed by immersion in cold $\left(4^{\circ} \mathrm{C}\right) 5 \%$ glutaraldehyde in $0 \cdot 1 \mathrm{~m}$-phosphate buffer (pH 7.3) for about 3 days. After primary fixation the tissues were washed with the buffer, secondarily fixed in $1 \%$ osmium tetroxide for $90 \mathrm{~min}$ and again washed with the buffer. After rapid dehydration through an alcohol sequence the tissues were embedded in Taab 812. Ultrathin sections were cut with an LKB UMIII ultramicrotome, and stained with aqueous uranyl acetate (Watson, 1958) and lead citrate (Reynolds, 1963) and examined using a Jeol JEM 100CXII transmission electron microscope.

Leydig cell activity was assessed by measuring the diameter of the largest lipid droplet in each of 10-20 Leydig cells from 2 specimens per month. Measurements were made from electron micrographs and these data were used to calculate mean monthly largest lipid droplet diameter.

Blood sampling. Blood was collected either from the cephalic vein in the wing or, when tissue was required for other purposes, specimens were killed and exsanguinated via the heart and anterior venae cavae. Samples were centrifuged at $1600 \mathrm{~g}$ and volumes of $\sim 100 \mu \mathrm{l}$ were stored at $-20^{\circ} \mathrm{C}$ until assayed. When blood was collected from the cephalic vein, plasma from two specimens was pooled to produce the $100 \mu \mathrm{l}$ aliquant. Exsanguination produced sufficient plasma and such samples were kept separate.

Testosterone assay. Plasma was assayed for testosterone and dihydrotestosterone using an RIA kit from Amersham (testosterone/dihydrotestosterone RIA kit, code TRK: 600: Radiochemical Centre, Amersham, Bucks, U.K.). 
Steroids other than testosterone that cross-react with the antibody are $5 \alpha$-dihydrotestosterone

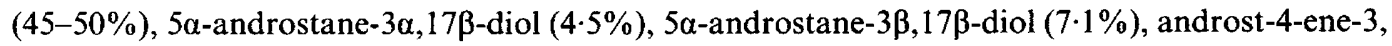
17 -dione $(2 \cdot 1 \%)$, and oestrone, oestradiol, progesterone, corticosterone and cortisol $(<0 \cdot 05 \%)$.

Plasma samples $(100 \mu \mathrm{l})$ were diluted to $1 \mathrm{ml}$ with distilled water and extracted with anhydrous diethyl ether. The aqueous phase was frozen and the organic (solvent) phase removed and evaporated to dryness. The residue was dissolved in $1.5 \mathrm{ml}$ of the Tris assay buffer ( $\mathrm{pH} 8.0$ ) and from $1 \mathrm{ml}$ of this solution the testosterone was denatured by an oxidation reaction, using a reagent supplied as part of the Amersham RIA kit. For each original plasma sample, this gave two samples, one with testosterone plus dihydrotestosterone and the other with dihydrotestosterone only.

A series of 7 testosterone standards $(0-400 \mathrm{pg} /$ tube) and 7 dihydrotestosterone standards $(0-800 \mathrm{pg} /$ tube $)$ and $200 \mu \mathrm{l}$ aliquants of plasma samples were prepared in duplicate for each assay. Then $200 \mu \mathrm{l} 5 \alpha$-dihydro- $\left[1,2,4,5,6,7-{ }^{3} \mathrm{H}\right]$ testosterone in ethanol and $200 \mu \mathrm{l}$ antibody (specific for both testosterone and dihydrotestosterone) were added to the assay tubes and incubated overnight at $25^{\circ} \mathrm{C}$. Antibody-bound steroids were separated from free steroids by addition of $200 \mu$ charcoal

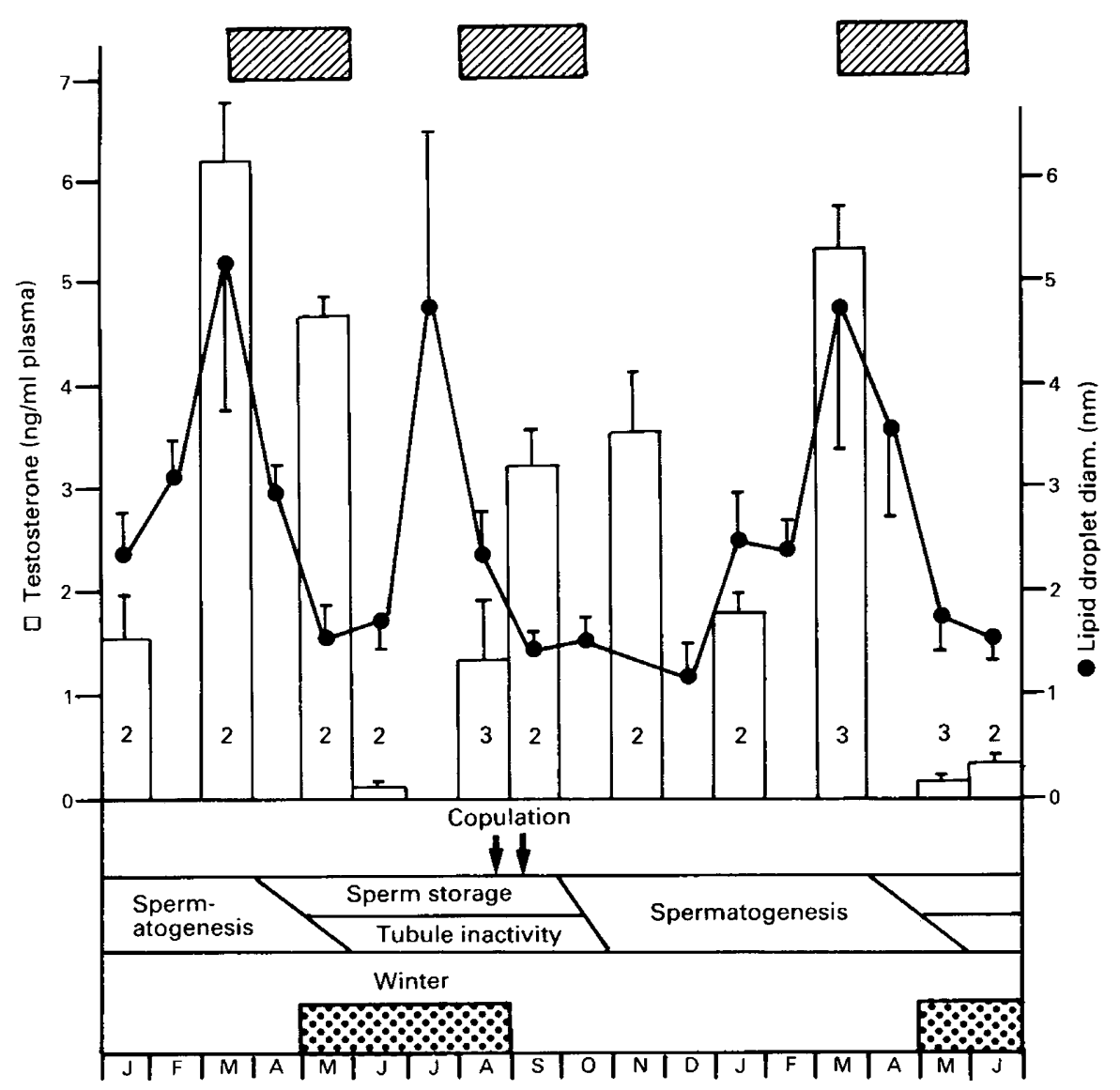

Fig. 1. Summary of the basic reproductive cycle of the Cape horseshoe bat illustrating changes in Leydig cell activity and plasma testosterone concentrations over an 18-month period (1983-mid-1984 for Leydig cells; 1984-mid-1985 for plasma testosterone). The hatched bars $(\mathbb{Z})$ indicate periods of Leydig cell secretory activity (determined by electron microscopy). Vertical lines indicate standard deviation. 
solution and centrifugation $(1600 \mathrm{~g})$. Then $500 \mu \mathrm{l}$ of the supernatant were added to $5 \mathrm{ml}$ of a scintillant (Lumax/toluene) and counted using a Beckman LS 3801 liquid scintillation counter.

The minimum detectable amount was $4 \mathrm{pg} /$ tube for testosterone plus dihydrotestosterone and $7 \mathrm{pg} /$ tube for dihydrotestosterone. Solvent blanks ( $1 \mathrm{ml}$ distilled water) were run with each set of biological samples and were always below $5 \mathrm{pg} /$ tube before oxidation, and below $11 \mathrm{pg} /$ tube after oxidation. Standards supplied with the kit were used as internal standards and added before ether extraction. Extraction efficiency was $72 \cdot 6 \pm 3 \cdot 1 \%(n=8)$ of the added $\left[{ }^{3} \mathrm{H}\right]$ dihydrotestosterone. Inter- and intra-assay coefficients of variation were $10 \cdot 4 \%$ and $5 \cdot 7 \%$ respectively. The assay was further validated using plasma from females which gave undetectable levels of testosterone.

Statistical analysis. Student's $t$ tests were used to test for statistically significant differences in mean monthly Leydig cell lipid droplet diameter, and accessory gland epithelial height from active and inactive tissues.

\section{Results}

\section{Reproductive cycle}

The reproductive cycle of the male Cape horseshoe bat (Fig. 1) was characterized by initiation of spermatogenesis in October with spermatozoa released to the cauda epididymidis in April and May. Between June and September, the seminiferous tubules were inactive and spermatozoa were stored in the cauda epididymidis. Copulation was asynchronous within the population and occurred at the end of winter, in August and September.

During winter (May to August) members of this species entered periods of hibernation that were interrupted by arousal during warm spells.

\section{Leydig cell activity}

Leydig cells were examined at an ultrastructural level for seasonal changes in the form and occurrence of lipid droplets, mitochondria and smooth endoplasmic reticulum (SER), three organelles that are associated with steroidogenesis. Monthly changes in lipid droplet diameter (Fig. 1) indicated that there were two periods of Leydig cell secretory activity, one in summer (March and April) and the second in late winter/early summer (July to September). The difference in lipid droplet diameter between March and July (1983) (the two peaks) was not significant $(0.05<P<0.1)$ but the differences between March and May, and July and October (1983) were significant $(P<0.001)$.

During the two periods of increasing lipid droplet diameter (January and February; June and July) the amount of SER in the cells increased and some formed characteristic concentric layers around the lipid droplets (Fig. 2). During the periods of peak and decreasing lipid droplet diameter

Fig. 2. Section through a Leydig cell from a specimen collected in March showing the typical steroidogenic appearance of this tissue. Note the wrapping of smooth endoplasmic reticulum (SER) around the lipid droplet (L), the mitochondria (M) with tubular (arrow) and lamellar cristae, and the numerous microsome-like vesicles (V). $\times 50400$.

Fig. 3. Typical appearance of the ampullary gland secretory epithelium during the period of inactivity showing the few, short microvilli (MV) and large autolytic vacuoles (AV). $\times 4060$.

Fig. 4. Section through an active ampullary gland secretory cell showing numerous, long microvilli (MV), secretory granules (SG) and small autolytic vacuoles (AV). $\times 8120$. 

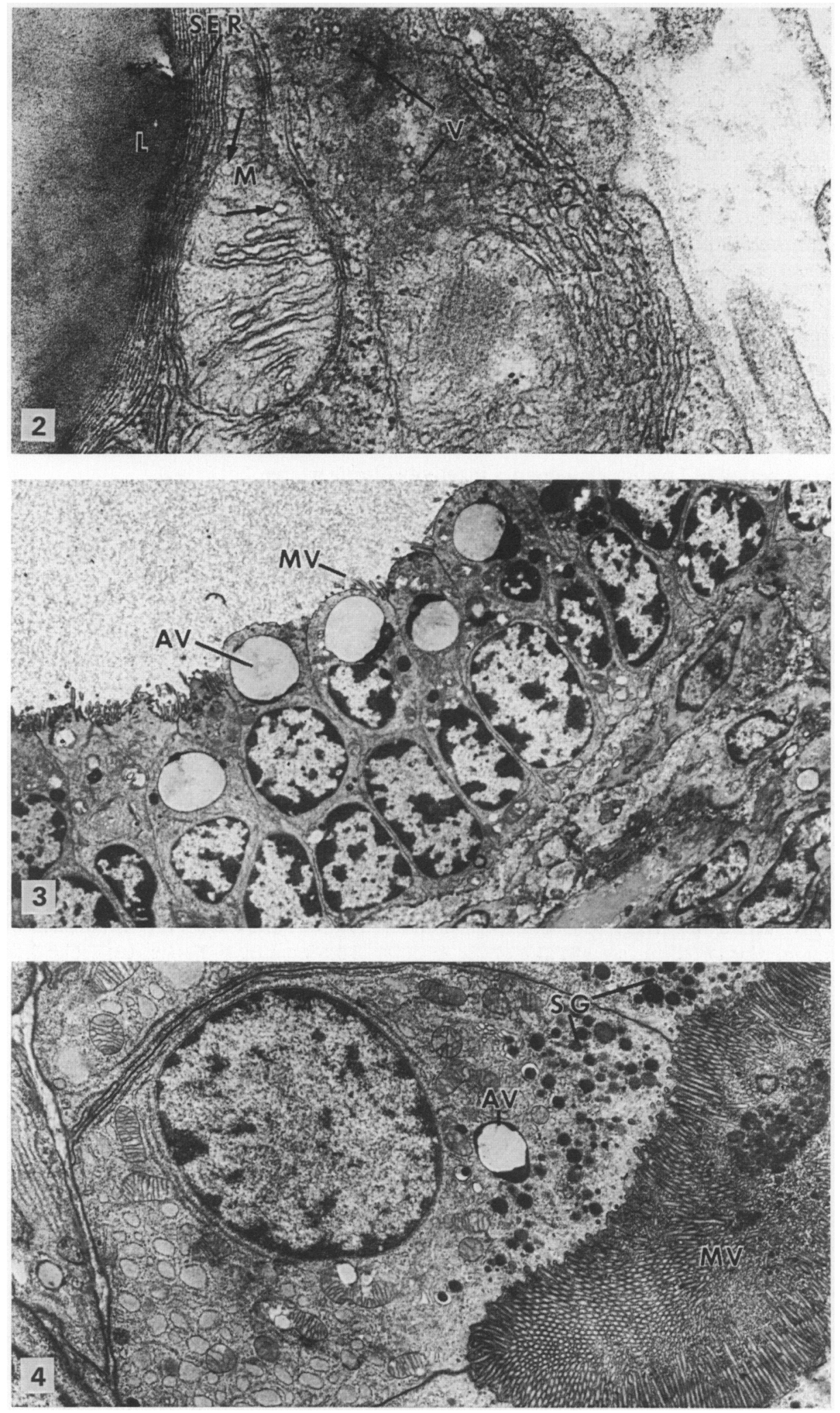
(March and April and July to September) the Leydig cells were filled with SER, much of which was in microsome-like vesicles (Fig. 2), and some of the mitochondria had tubular or tubular and lamellar cristae. In the non-secretory condition the Leydig cells were characterized by more abundant rough endoplasmic reticulum, decreased amounts of SER, and mitochondria with only lamellar cristae.

\section{Blood testosterone concentrations}

Dihydrotestosterone was not detectable in any of the plasma samples and the measurement of plasma testosterone plus dihydrotestosterone has been used without correction.

Within 1 calendar year there were two periods of increasing and peak plasma testosterone concentrations (Fig. 1). The first, in late summer, coincided closely with the period of Leydig cell activity while the second, early the following summer, preceded the period of Leydig cell activity by about 1 month.

Both Leydig cell ultrastructure and plasma testosterone concentrations (Fig. 1) indicated that there was a period of Leydig cell secretory inactivity during winter.

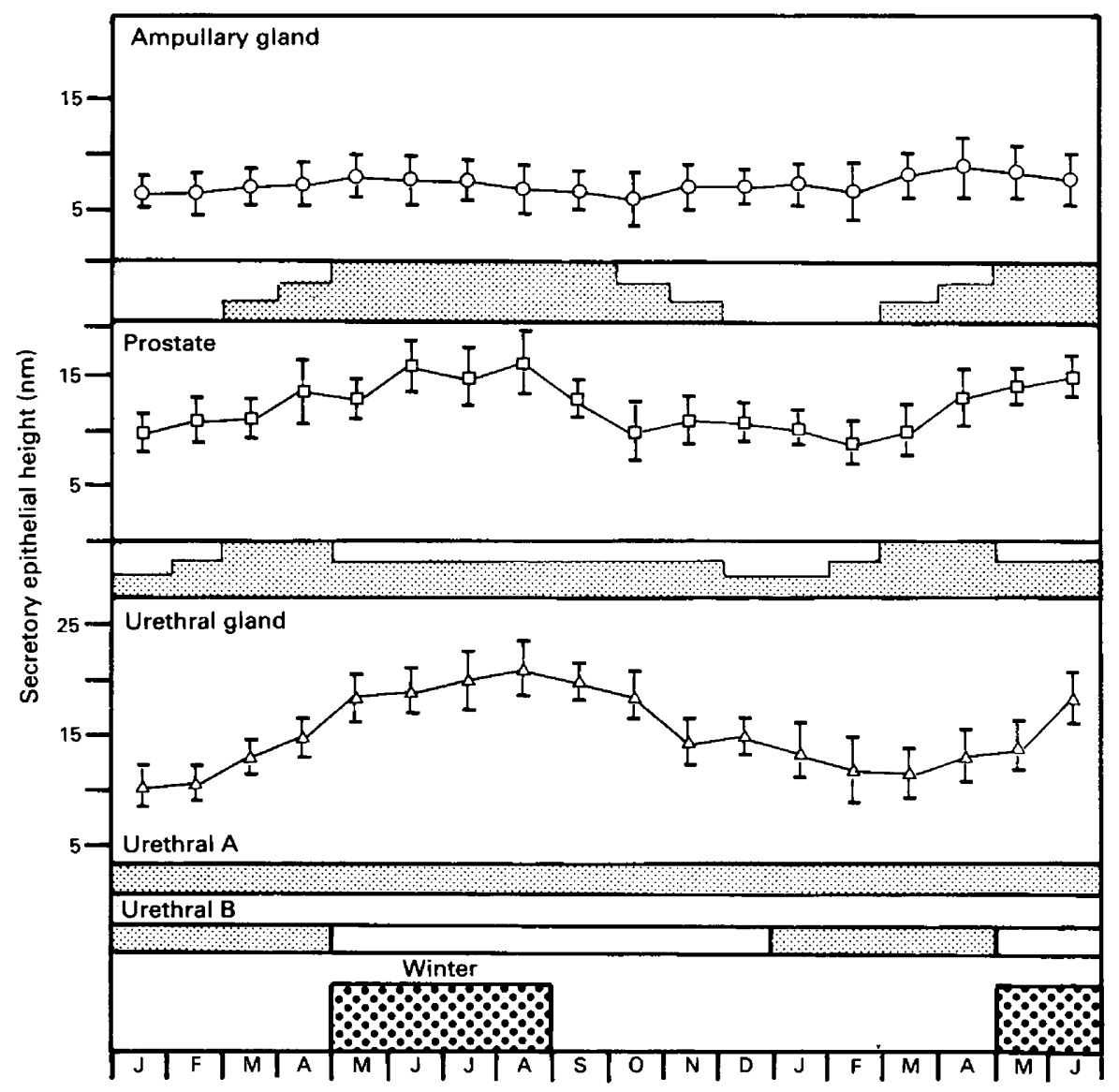

Fig. 5. Summary of accessory gland activity over an 18-month period. Graphs show changes in mean monthly secretory epithelial height. The horizontal shaded block diagrams represent periods of secretory activity, as determined by electron microscopy and histochemistry. Vertical lines indicate standard deviation. 


\section{Accessory gland activity}

The accessory complex of the Cape horseshoe bat was located at the base of the bladder and comprised paired ampullary glands, a single prostate, and single large urethral gland.

The ampullary gland was a compound alveolar gland with large alveoli and a thin cuboidal secretory epithelium. At a light microscope level the cellular structure of this gland did not change during 1 calendar year. There was no significant change in mean monthly secretory epithelial height between the active (May) and the inactive (January) conditions $(P>0 \cdot 1)$ (Fig. 5) and the lumina always contained secretion. However, at an ultrastructural level there was an obvious period of regression and inactivity between October/November and March, when the secretory epithelial cells were characterized by few, short microvilli, a single large autolytic vacuole, and few secretory granules (Fig. 3). In the active condition, the microvilli were more numerous and longer, there were large numbers of secretory granules in the apices of the cells, and few, small autolytic vacuoles (Fig. 4).

The prostate was a compound tubular gland with a columnar secretory epithelium. Changes in epithelial height (Fig. 5) indicated that there was a period of secretory activity between April and September, and the difference in epithelial height between the active (August) and inactive (January) conditions was significant $(0.01<P<0.02)$. The secretion of the prostate stained positively with PAS and this stain was used to assess secretory activity. There was some secretory activity throughout the year, with an increased amount of secretion between March and September, and a peak during March and April (Fig. 6).

The urethral gland was a compound tubular gland with a columnar secretory epithelium (termed urethral A cells) and a second cell type (termed urethral B cells) located below the columnar cells and which secreted into the urethral lumen (Fig. 7). Changes in mean monthly epithelial height of the urethral A cells (Fig. 5) indicate that there was a period of activity between March and October, and mean epithelial height in August was significantly different from that in January $(0.001<P<0.002)$. However, at a light microscope level, the columnar urethral A cells showed evidence of secretory activity, in the form of blebbing from the apical cytoplasm throughout the year. Observations at an ultrastructural level (Fig. 7) showed that the cells contained and released secretory vesicles throughout the year. The secretion of the urethral B cells was positive to alcian blue and with this stain it was apparent that although the cells contained secretory material throughout the year, secretion was released only between January and April (Fig. 8). Accessory gland activity is summarized in Fig. 5.

\section{Discussion}

The reproductive cycle of the Cape horseshoe bat differs from those described for temperate-zone, hibernating members of the genus Rhinolophus (see Gustafson, 1979, for review) in that although spermatozoa are released to the cauda epididymidis before winter, copulation occurs at the end of winter only. Since the seminiferous tubules are inactive during winter, this illustrates that the spermatozoa retain their fertilizing ability for the duration of the period of sperm storage. Although the onus of sperm storage in the Cape horseshoe bat is on the male alone, prolonged storage of spermatozoa by the male has been reported in some rhinolophids and vespertilionids from north temperate regions (Aubert, 1963; Racey, 1979).

Recent studies of cellular organization for steroidogenesis have highlighted the roles of lipid droplets, mitochondria, and SER (see Hall, 1984, for review) and it has been suggested that SER may be the most reliable morphological indicator of steroidogenic activity. Ultrastructural studies of bat Leydig cells (Gustafson, 1976; Ohata, 1979; Loh \& Gemmell, 1980; present study) have shown that seasonal changes in lipid droplet diameter, mitochondrial cristae profiles and the form and amount of SER do occur and can be related to testosterone production. However, as the present study indicates that testosterone is produced throughout the year, the visible changes in Leydig cell organelles should be correlated with peaks of testosterone production rather than simply Leydig cell steroidogenic activity. 


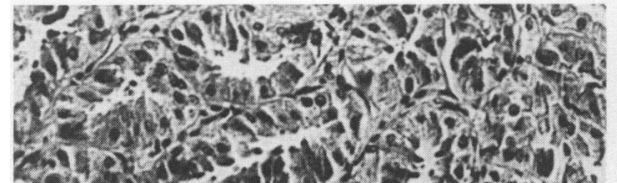

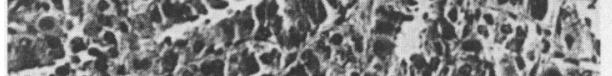

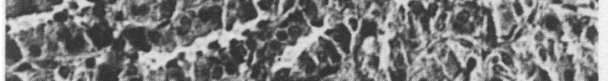

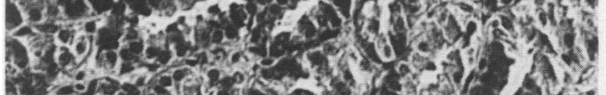

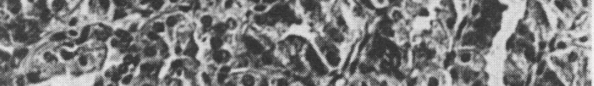

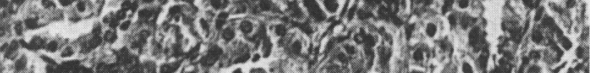

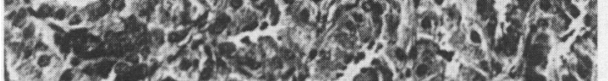

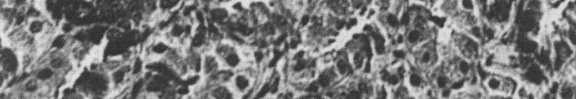

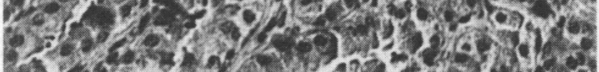

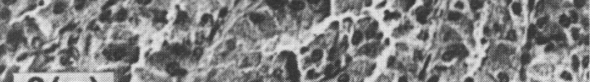
6(a) 6 (a)
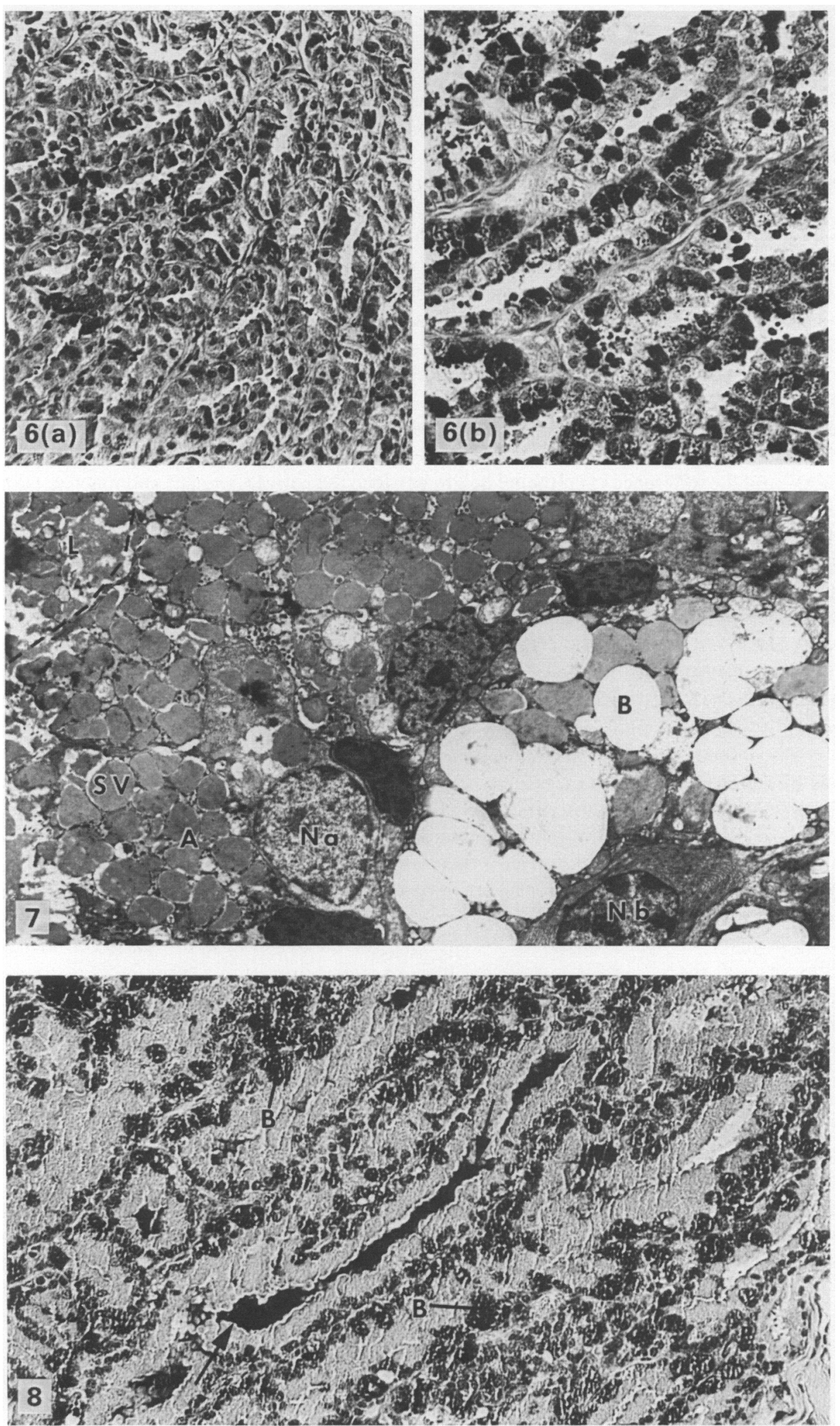
The monthly changes in plasma testosterone concentrations show three major characteristics; an increase and peak in late summer at the time of spermiogenesis, a reduction in winter, and a second peak in late winter/early summer. The close correlation between Leydig cell activity and peak plasma testosterone concentrations in March/April and the gap between Leydig cell activity and peak plasma testosterone values between August and October are probably artefacts, resulting from the collection of testicular material and blood in subsequent years (see 'Materials and Methods'). The association between spermiogenesis and peak testosterone concentrations has been widely reported in mammals and corresponds with the limited data for bats (Racey, 1974; Racey \& Tam, 1974; Gustafson \& Shemesh, 1976; Krutzsch, Watson \& Lox, 1976; Beasley, 1984).

The occurrence of non-secretory Leydig cells and low plasma testosterone concentrations in winter is significant. To date, members of the Rhinolophidae have been placed in the 'Pipistrellus pattern' (active Leydig cells and active accessory glands during winter) (Gustafson, 1979). However, results for the Cape horseshoe bat indicate that it may better fit the 'Myotis pattern' (inactive Leydig cells and active accessory glands during winter). The occurrence of Leydig cell inactivity in winter in the Cape horseshoe bar at $\sim 33^{\circ} \mathrm{S}$ supports the suggestion that the two patterns of Leydig cell activity may represent a latitudinal effect on the later stages of the pituitary-gonad cycle (Leydig cell regression) (Racey, 1982). Favourable conditions during autumn, at latitudes below $42^{\circ}$, may allow the Leydig cells to regress before winter, while at latitudes above $45^{\circ}$ hibernation may interfere sooner, and retard Leydig cell regression which would be completed in the following spring (Racey, 1982).

The second peak of plasma testosterone is possibly associated with stimulation of copulatory behaviour since there is an indication that copulation may be associated with elevated plasma testosterone concentrations (Setchell, 1978). There are however, no corresponding data for bats since in those species for which plasma testosterone values are available, copulation occurs at the end of spermatogenesis when testosterone concentrations are elevated. It is possible that the second peak is associated with the initiation of a new cycle of spermatogenesis and similar peaks have been reported for some vespertilionids (Racey, 1974; Racey \& Tam, 1974; Beasley, 1984). The testosterone concentrations measured in the Cape horseshoe bat (maximum $6.58 \mathrm{ng} / \mathrm{ml}$; minimum $0.32 \mathrm{ng} / \mathrm{ml}$ ) fall within the wide range reported for other microchiropterans (Loh \& Gemmell, 1970; Racey, 1974; Racey \& Tam, 1974; Gustafson \& Shemesh, 1976; Krutzsch et al., 1976).

The pattern of continued winter accessory gland activity in the Cape horseshoe bat is similar to that described for other hibernating rhinolophids. However, the Cape horseshoe bat differs in that increasing or peak secretory activity of the prostate, urethral B cells and ampulla coincides with increasing or peak plasma testosterone concentrations. The apparent continued secretory activity during winter may be androgen-independent.

A specific sex steroid binding protein (SBP) has been identified in the plasma of the little brown

Fig. 6. Sections through the prostate from specimens collected (a) in January showimg minimal PAS positive material in the cells and the lumen, and (b) in April showing the increased PAS-positive reaction associated with peak activity. $\times 310$.

Fig. 7. Electron micrograph of part of the secretory epithelium of the urethral gland showing the typical appearance of the two cell types. The type A cells (A) contain numerous secretory vesicles (SV), some of which have been released into the lumen (L). The type B cell (B) is located below the type $A$ cells and contains larger secretory vesicles. The broken line indicates the approximate position of the border between the type $\mathrm{A}$ cells and the lumen. $\mathrm{Na}$, nucleus of $\mathrm{A}$ cell; $\mathrm{Nb}$, nucleus of $\mathrm{B}$ cell. $\times 4060$.

Fig. 8. Light micrograph of urethral gland tissue from a specimen collected in March and stained with alcian blue. Note the accumulation of secretory material from the type $\mathbf{B}$ cells in the lumen (arrows), and the position of the type B cells (B). $\times 310$. 
bat (M. lucifugus) (Damassa, Gustafson \& King, 1982) in which it is thought to play a major role in the delayed reactivation of the accessory organs (Gustafson \& Damassa, 1985). It is not known whether SBP occurs in the Cape horseshoe bat but two lines of evidence suggest that, if it does occur, its role is not important. Firstly, the asynchrony in reactivation of the seminiferous tubules and accessory glands is not as marked as in the little brown bat, and secondly, for certain components of the accessory complex, secretory activity coincides with peak testosterone values.

In considering the biological significance of the differences between the reproductive cycles of the Cape horseshoe bat and those of north temperate-zone, hibernating rhinolophids it is notable that the reproductive cycle of the former has characteristics of both the tropical reproductive cycle (no female sperm storage) and the temperate reproductive cycle (spermatogenesis before winter), and as such may represent an evolutionary intermediate. On the other hand, since the typical reproductive cycle of north temperate-zone hibernating rhinolophids is regarded as an adaptation to overcome the problems resulting from prolonged hibernation, it is reasonable to expect a species from a lower latitude, with a different pattern of hibernation, to show a different reproductive cycle.

I thank Professor B. R. Allanson and Dr A. N. Hodgson for critically reading drafts of this paper, Professor A. W. Gustafson and Dr E. Anthony for some useful discussions, the staff of the Rhodes University Electron Microscopy Unit, and Mr K. Sheppey and G. Quibell for technical assistance, and Rhodes University who funded the research.

\section{References}

Aubert, A. (1963) Observations sur l'accouplement des chiroptères. Acta theriol. 6, 300-301.

Beasley, L.J. (1984) Melatonin influences the reproductive physiology of male pallid bats. Biol. Reprod. 30, 300-305.

Bernard, R.T.F. (1985) Reproduction in the Cape horseshoe bat (Rhinolophus capensis) from South Africa. $S$. Afr. J. Zool. 20, 129-135.

Courrier, R. (1927) Etude sur le déterminisme des charactères sexuels secondaires chez quelques mammifères a activité testiculaire périodique. Archs Biol. 37, 173-334.

Damassa, D.A., Gustafson, A.W. \& King, J.C. (1982) Identification of a specific binding protein for sex steroids in the plasma of the male little brown bat, Myotis lucifugus lucifugus. Gen. comp. Endocrinol. 47, 288-293.

Gustafson, A.W. (1976) A study of the annual male reproductive cycle in a hibernating vespertilionid bat (Myotis lucifugus lucifugus) with emphasis on the structure and function of the interstitial cells of Leydig. Diss. Abstr. B 36, 4792-4793.

Gustafson, A.W. (1979) Male reproductive patterns in hibernating bats. J. Reprod. Fert. 56, 317-331.

Gustafson, A.W. \& Damassa, D.A. (1985) Annual variation in plasma sex steroid binding protein and testosterone concentrations in the adult male little brown bat: relation to the asynchronous recrudescence of the testes and accessory reproductive organs. Biol. Reprod. 33, 1126-1137.

Gustafson, A.W. \& Shemesh, M. (1976) Changes in plasma testosterone levels during the annual reproductive cycle of the hibernating bat Myotis lucifugus lucifugus with a survey of plasma testosterone levels in adult male vertebrates. Biol. Reprod. 15, 9-24.

Hall, P.F. (1984) Cellular organization for steroidogenesis. Int. Rev. Cytol. 86, 53-94.
Krutzsch, P.H., Watson, R.H. \& Lox, C.D. (1976) Reproductive biology of the male leaf-nosed bat Macrotus waterhousii in Southwestern United States. Anat. Rec. 184, 611-636.

Loh, H.S.F. \& Gemmell, R.T. (1980) Changes in the fine structure of the testicular Leydig cells of the seasonally-breeding bat Myotis adversus. Cell Tissue Res. 210, 339-347.

Ohata, M. (1979) Electron microscope studies of the bat testicular interstitial tissue cell with special reference to cytoplasmic crystalloids. Arch. histol. jap. 42, 103-118.

Racey, P.A. (1974) The reproductive cycle in male noctule bats, Nyctalus noctula. J. Reprod. Fert. 41, 169-182.

Racey, P.A. (1979) The prolonged storage and survival of spermatozoa in Chiroptera. J. Reprod. Fert. 56, $391-402$.

Racey, P.A. (1982) Ecology of bat reproduction. In Ecology of Bats, pp. 57-104. Ed. T. Kunz. Plenum, New York.

Racey, P.A. \& Tam, W.H. (1974) Reproduction in male Pipistrellus pipistrellus (Mammalia:Chiroptera). $J$. Zool., Lond. 172, 101-122.

Reynolds, E.S. (1963) The use of lead citrate at high $\mathrm{pH}$ as an electron opaque stain in electron microscopy. $J$. Cell Biol. 17, 208-212.

Setchell, B.P. (1978) The Mammalian Testis, pp. 109-180. Paul Elek, London.

Watson, M.L. (1958) Staining of tissue sections for electron microscopy with heavy metals. J. Biophys. Biochem. Cytol. 4, 475-478.

Wimsatt, W.A. (1969) Some interrelations of reproduction and hibernation in mammals. Symp. Soc. exp. Biol. 23, 511-549. 